\title{
"Financial performance under stress: the case of the Norwegian maritime cluster"
}

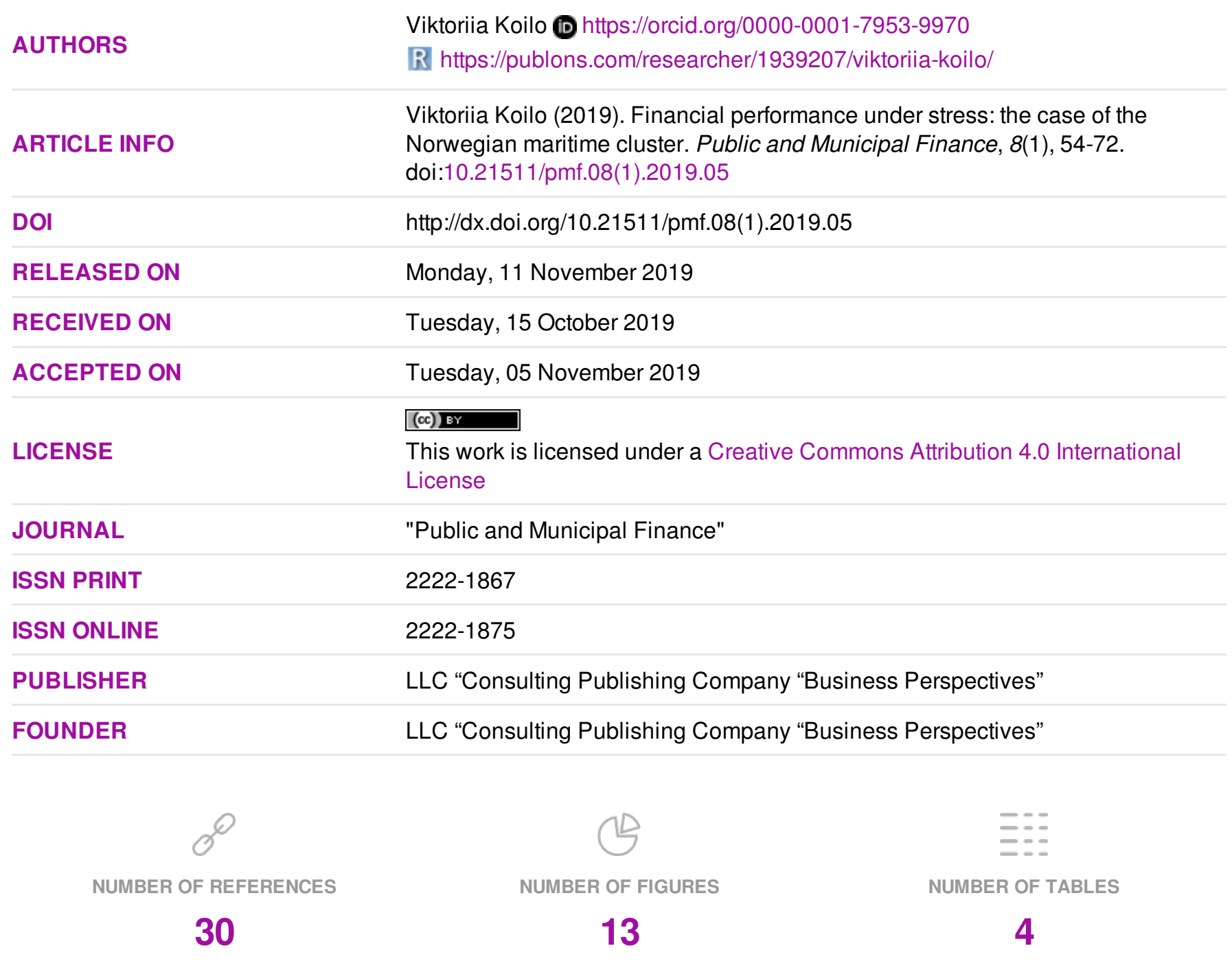

(C) The author(s) 2022. This publication is an open access article. 


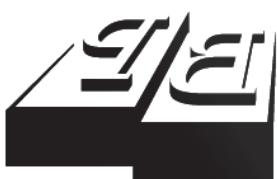

BUSINESS PERSPECTIVES

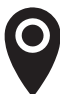

LLC "CPC "Business Perspectives" Hryhorii Skovoroda lane, 10, Sumy, 40022, Ukraine

www.businessperspectives.org

Received on: $15^{\text {th }}$ of October, 2019 Accepted on: $5^{\text {th }}$ of November, 2019

(C) Viktoriia Koilo, 2019

Viktoriia Koilo, Associate Professor, Ph.D., Hauge School of Management, NLA University College, Norway.

\section{(ㄷ)(1) $(8)$}

This is an Open Access article, distributed under the terms of the Creative Commons Attribution-NonCommercial 4.0 International license, which permits re-use, distribution, and reproduction, provided the materials aren't used for commercial purposes and the original work is properly cited.

\title{
FINANCIAL PERFORMANCE UNDER STRESS: THE CASE OF THE NORWEGIAN MARITIME CLUSTER
}

\begin{abstract}
The present study investigates the Norwegian maritime industry in terms of its economic activity during the period 2001-2018. The purpose of the study is to determine the financial state and to conduct the cluster analysis of the companies which belong to the Blue Maritime Cluster of Møre and Romsdal County.

The paper presents a structural analysis of key financial indicators of the maritime industry within four major segments: shipping companies, shipyards, ship equipment manufactures, and maritime design and service providers. The analysis sheds light on the impact of the 2015-2017 offshore crisis on the Norwegian maritime cluster activity, which makes up the essential components of the maritime industry.

The author suggests using Harrington's desirability function to measure the firms' financial state of two main segments (shipping companies and shipyards) that belong to the Blue Maritime Cluster of the Norwegian North-Western coast, which remains the most important area in Norway for shipbuilding activities. The obtained results reveal that during the analyzed period (2001-2018), companies had a satisfactory level of financial sustainability (with the peak in 2002 for shipping firms and in 2011 for shipyards). Nevertheless, there were several fluctuations and the most significant troughs were fixed after 2014. Moreover, it was defined that government policy plays an important role in an increase in the productivity, competitiveness of the maritime industry and supports more environmentally friendly shipbuilding.
\end{abstract}

\section{Keywords}

\section{JEL Classification L25, L98, Q48}

\section{INTRODUCTION}

Norway, more than any other nation, took advantage of abandonment of the British Navigation Act in 1850. Hence, the maritime sector of the Norwegian economy grew fast, and country had the world's thirdlargest ocean-going fleet in terms of tonnage in 1875. In 2019 Norway still is one of the leading maritime nations in the world, despite many historical challenges. In the last decades of the nineteenth century, Norway had a late transition from sail to steam, and it lost huge parts of its fleet during both world wars.

In the 1970s and 1980s, Norway experienced huge problems both to its shipyards and its ocean-going fleet, due to high domestic costs.

Since 2014 the significant reduction in maritime operations connected with offshore oil and gas production constitutes its main present challenge.

Traditionally, it is believed that Norway is one of the nations that have a complete maritime cluster. Moreover, a significant interdependency 
between actors within the maritime industry and a strong emphasis on innovation and technological leadership allow Norway to maintain a unique industrial cluster.

The maritime industry plays a significant role in the Norwegian business. In 2018 the industry contributed 142 billion NOK (Norwegian krones) in value creation, and thus accounts for eight percent of Norwegian GDP (excluding oil and gas operations). At the same time, the maritime companies employed around 85,000 people in 2018 (Menon, 2019). Value creation per employee is around 80 percent higher in the maritime industry than in the rest of the business sector (excluding the oil operators).

The Norwegian maritime cluster makes up a unique model in the way that competitors, customers, and suppliers work closely. Hence, continuous monitoring of sustainability indicators is an important precondition for ensuring the stable activity of both individual enterprise and the whole maritime cluster. Nowadays, the issue of sustainable development is of prior importance. Each industry should constantly do the monitoring of sustainability criteria. It is clear that any change in the conditions of the external or internal environment will have some impact on the performance of the company, especially this influence is strongly observed in those fields, which have a tight relationship between the interconnected businesses within the same cluster.

It should be mentioned that business plays a major role in achieving sustainable development goals (SDGs), thus it is important to keep companies' leading position and ensure further innovation and technological development. Nevertheless, in recent years, the economic activity of firms, which belong to the Norwegian maritime cluster, appears to have slowed down due to the offshore crisis 2015-2017.

Presently, companies, on the one hand, should keep their position in the market and competitiveness on the world level, and stay forerunners in the gaining of SDG, on the other hand. Thus, it is necessary to conduct an analysis to check the position of the Norwegian maritime industry and to do a detailed structural analysis of the key financial indicators of the companies within the cluster.

The aim of this paper is twofold.

Firstly, it seeks to give an analytical mapping of the state of the Norwegian maritime industries after the offshore crisis in 2014 until present.

Secondly, the paper offers a cluster analysis in order to check the Norwegian maritime industries strategic strength in light of future challenges and the green shift.

Hence, it is necessary to conduct further analysis and to shed light on the main research questions.

\section{LITERATURE REVIEW}

European experience convincingly demonstrates the effectiveness and regularity of the emergence of different types of clusters. During the last decades, clusters have become an important part of the government policy of many EU members. The European Cluster Memorandum (2008), the Vienna Clustering Manifesto (2012) identified cluster development as a major mech- anism for enhancing the competitiveness of European economies by identifying the priorities of national programs.

Cluster is a long-observed phenomenon and was first mentioned 125 years ago. An in-depth analysis of the concept was introduced by Porter $(1990,1998)$. In his study, he mentions that clusters are the most competitive advantages of nations and argues that they play a significant 
part in different aspects of the country's performance: economic, social development, innovation leadership, and competitiveness. He also underlines that clusters are 'geographical concentrations of interconnected companies and institutions in a particular field' (Porter, 1998).

Spencer, Vinodrai, Gertler, and Wolfe (2010) define a cluster as co-location of the specialized industry and other related industries.

As noted by Meersman and Voorde (1997), a maritime cluster includes a range of firms, whose activities are directly related to maritime. Several authors underline that there are also different types of firms in the services sector, which are included in the maritime clusters as well due to their close links with maritime companies. In fact, as noted by Voorde (2005), firms that provide maritime transport services and port services are also part of the maritime industry. Moreover, a maritime cluster also comprises of those companies, which provide research, financial and support services for maritime companies (Cluster Maritimo Espanol, 2006).

To sum up, a maritime cluster can be defined as follows: a territorial-sectoral voluntary formal or informal association of port companies, organizations, and related industries. The members are developing and maintaining a maritime complex structure in cooperation with scientific, educational, financial, consulting and other organizations and local authorities. This is done to enhance the level of competitiveness of all participants. in the integration and economic growth of the coastal region and country in general.

It should be mentioned that peculiarities of the creation and operation of maritime clusters can be identified by different schemes (European Commission, 2008):

1) top-down approach (agglomerative model), as was done in Germany, Slovenia, and Denmark, where support measures have more strategic coherence and initiated by the private cluster actors;

2) bottom-up approach (divisive model), such as in Norway, Hungary, and Belgium, character- ized by a strong involvement of government authorities;

3) combined approach (hybrid model) is presented in Poland and Latvia, where bottom-up processes are combined with a top-down selection of competitive clusters in a global scale (Maticiuc, 2014).

Several authors underline the economic advantages of maritime clusters, concluding that direct and indirect economic impacts make maritime industries of vital importance to society (Hansen \& Clasen, 2010). Similarly, Wihlborg (2006), Wijnolst, Jenssen, and Sodal (2008), Doloreux and Shearmur (2009), Vanaale (2012) focus their attention on the economic impact in terms of providing with working places and country's value creation, and how it can be evaluated.

Other kinds of economic significance were presented by Porter (1998). He argues that a cluster is an important factor for creating more favorable market conditions. In addition, several scholars (Langlois \& Robertson, 1996) focus their attention on technological externalities, which arise through shared technological information and knowledge spillovers within the cluster.

Nevertheless, clusters can have both positive and negative impacts. For instance, in a survey of the Blue Maritime Cluster, one finds that narrow focused supply chain management made the cluster fall deep into the abyss when shipping companies and shipyards were hit after the offshore crisis (Koilo \& Grytten, 2019). Especially this problem strongly affected the labor market in the maritime industry. According to the OECD's report "Competitive Regional Clusters: Approaches to National Policies" (OECD, 2007), the problem of creating and operating clusters in the world needs to address the following issue first - what is more important in terms of cluster support is the retention and development of jobs or the cultivation of new strategically important technologies.

Therefore, it is necessary to carry out this study that will allow us to get a general picture of the current economic situation of the maritime industry and to check whether it is possible for companies to meet SDGs in an established time manner. 


\section{MAIN TRENDS}

\section{AND PATTERNS}

IN THE NORWEGIAN

\section{MARITIME INDUSTRY}

Norwegian maritime industries constitute the second-largest export branch in Norway, after oil and gas. The cluster is well-known globally due to the country's large merchant fleet. Shipping is inextricably linked to international trade. The total world ocean-going fleet consists of about 50,000 ships. These are distributed across a wide range of ship types. For example, it is approximately 12,000 tankers, 3,500 container ships and 6,000 passenger ships in the total fleet (UNCTAD, 2019).

Most Norwegian commercial ships are registered under a flag that differs from the flag of the country of ownership: Norwegian fleet consists of 549 vessels, which fly under the Norwegian flag and 1,433 foreign or international flag, and the share of the dead-weight tonnage of a national flag in total is $8.3 \%$. The registers specialize in different vessel types (Figure 1).

Concerning the commercial value, almost 68 percent of the offshore fleet is registered in the Norwegian Ordinary Ship Register (NOR). Seventy-three percent of the ferry and passenger ship fleet is registered in NOR. Other vessels, including oil tankers, dry bulk carriers, general cargo ships, gas carriers, chemical tankers, have dom- inant registration in the Norwegian International Ship Register (NIS). Table 1 provides information on the Norwegian merchant fleet by country of beneficial ownership.

Table 1. Norwegian merchant fleet by country of beneficial ownership, annual, 2014-2018

Source: UNCTAD (2019)

\begin{tabular}{|c|c|c|}
\hline Flag of registration & $\begin{array}{l}\text { Deadweight tons } \\
\text { in thousands }\end{array}$ & $\%$ \\
\hline Norway & 15687,03 & 26.42 \\
\hline Other flags & 9883,71 & 16.64 \\
\hline Marshall Islands & 7299,43 & 12.29 \\
\hline Bahamas & 6824,69 & 11.49 \\
\hline China, Hong Kong SAR & 5515,86 & 9.29 \\
\hline Isle of Man & 3052,38 & 5.14 \\
\hline Panama & 3053,04 & 5.14 \\
\hline Liberia & 2932,43 & 4.94 \\
\hline Singapore & 2007,8 & 3.38 \\
\hline Malta & 1057,87 & 1.78 \\
\hline Spain & 1018,49 & 1.72 \\
\hline $\begin{array}{l}\text { UK of Great Britain and } \\
\text { Northern Ireland }\end{array}$ & 531,65 & 0.9 \\
\hline Cyprus & 232,86 & 0.39 \\
\hline Denmark & 162,86 & 0.27 \\
\hline Indonesia & 117,97 & 0.2 \\
\hline Greece & 2,35 & 0 \\
\hline Total all flags & 59380,4 & 100 \\
\hline
\end{tabular}

Here "Ownership" refers to "Beneficial ownership location." Norwegian merchant fleet has four main countries of beneficial ownership: Norway with $27 \%$, the Marshall Islands with $17 \%$, Bahamas with $12 \%$, and Hong Kong with $12 \%$.

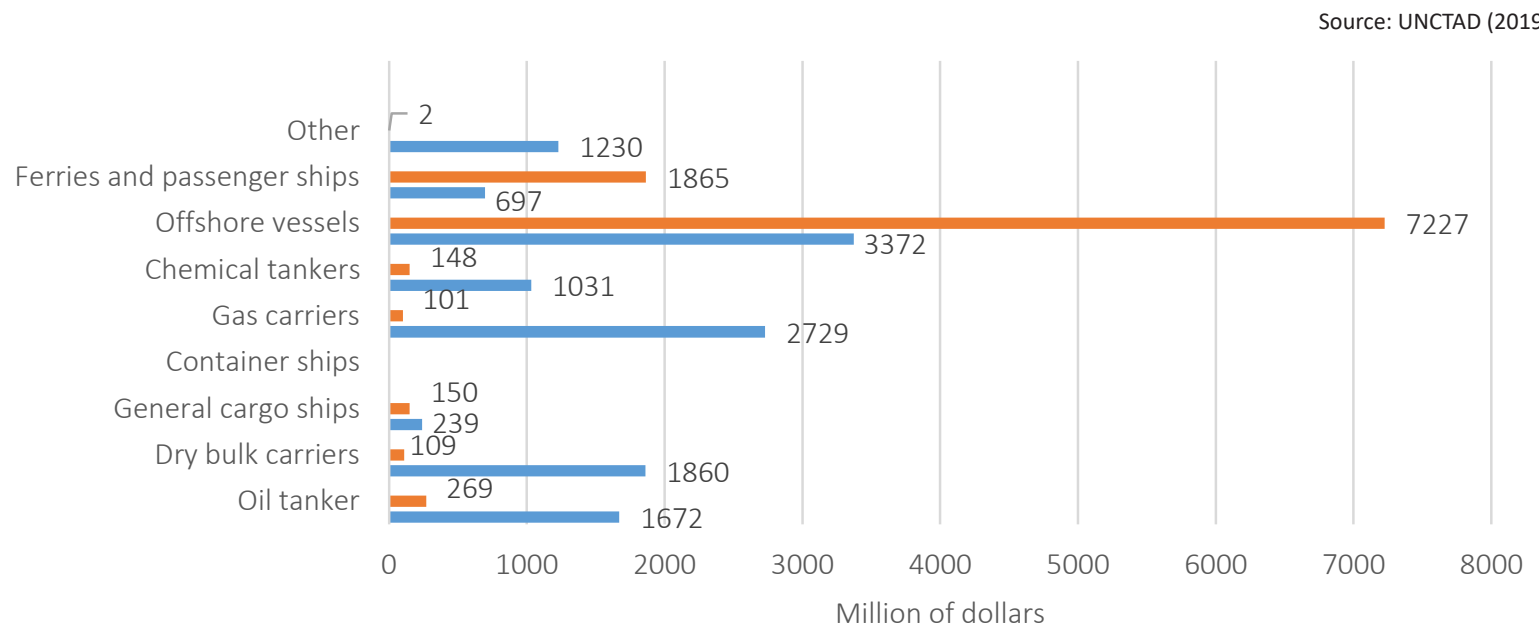

Figure 1. Norwegian fleet by flag of registration and the value of the ship type, 2018 
Table 2. Regionally distributed key figures for the maritime industry in 2018

Source: Menon (2019).

\begin{tabular}{|c|c|c|c|}
\hline Region & Turnover (billion NOK) & Employed & Value creation (billion NOK) \\
\hline The Oslofiord area & 125.0 & 18,586 & 41.2 \\
\hline The Bergen area & 89.1 & 14,961 & 28.5 \\
\hline The Stavanger area & 57.1 & 13,157 & 20.9 \\
\hline Møre og Romsdal & 53.1 & 12,569 & 14.7 \\
\hline Haugaland/Sunnhordland & 26.8 & 7,752 & 13.8 \\
\hline Southern Norway & 30.4 & 7,280 & 9.9 \\
\hline Northern Norway & 19.8 & 6,920 & 7.6 \\
\hline Trøndelag & 13.5 & 4,040 & 5.3 \\
\hline Total & 414.9 & 85,266 & 142 \\
\hline
\end{tabular}

Also, it should be mentioned that maritime companies play a key role in terms of value creation, e.g., in 2018, total value added was 142 billion NOK (Table 2).

In general, the Norwegian maritime cluster consists of eight main regions. Those employed in the maritime industry are spreading throughout the country, with a natural predominance along the coast.

It should be mentioned that Møre og Romsdal is one of the leading centers in the maritime industry, where regional shipping companies controlled $40 \%$ of the world's most advanced offshore fleet (Koilo \& Grytten, 2019).

Nevertheless, since the peak in 2014, value creation in the maritime industry has decreased significantly, and value creation fell by about 30\% from 2014 to 2017. The crisis was basically caused by considerable significant contraction of oil and gas prices in 2014, hence, it led to an activity downturn in the offshore oil industry. This made a huge share of the ocean-going fleet redundant and shipyard activity felt significantly (Koillo \& Grytten, 2019).

Figure 2 illustrates that in 2018, there was moderate growth in the industry of 5\% and a further $6 \%$ growth in 2019. Employment initially depends on the value creation, with near-zero growth in 2018 and expectations of a slight increase in 2019.

It is interesting to note that for a long time, international shipping constituted the largest part of the maritime industry in Norway. The number of maritime industries targeting oil and gas grew explosively from the 1980s with a new spurt from the early 2000s. This over-took goods transport as the most important market segment around 2006.

The current study finds that after a slight break during the financial crisis in 2009, growth continued in the oil-oriented part of the industry, with overall turnover growth of more than 50 percent from 2010 to 2014. At the same time, the development in

Source: Menon (2019).

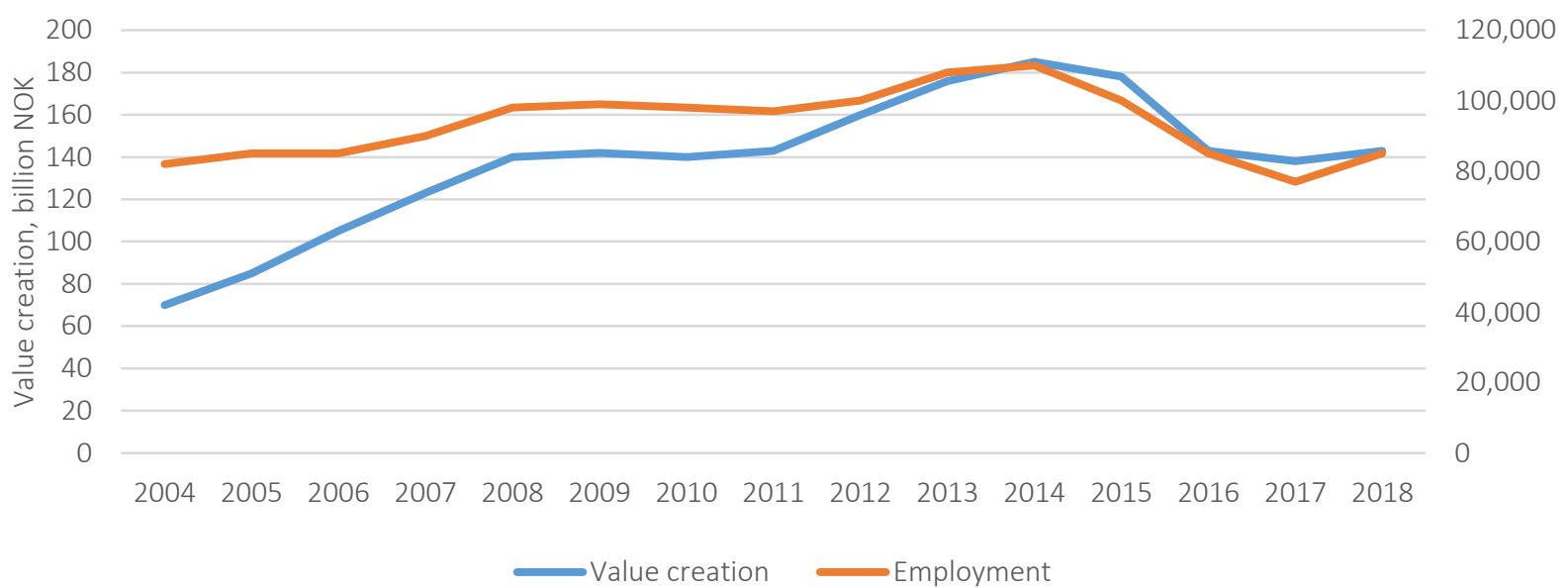

Figure 2. Value creation and employment in the maritime industry (2004-2019) 


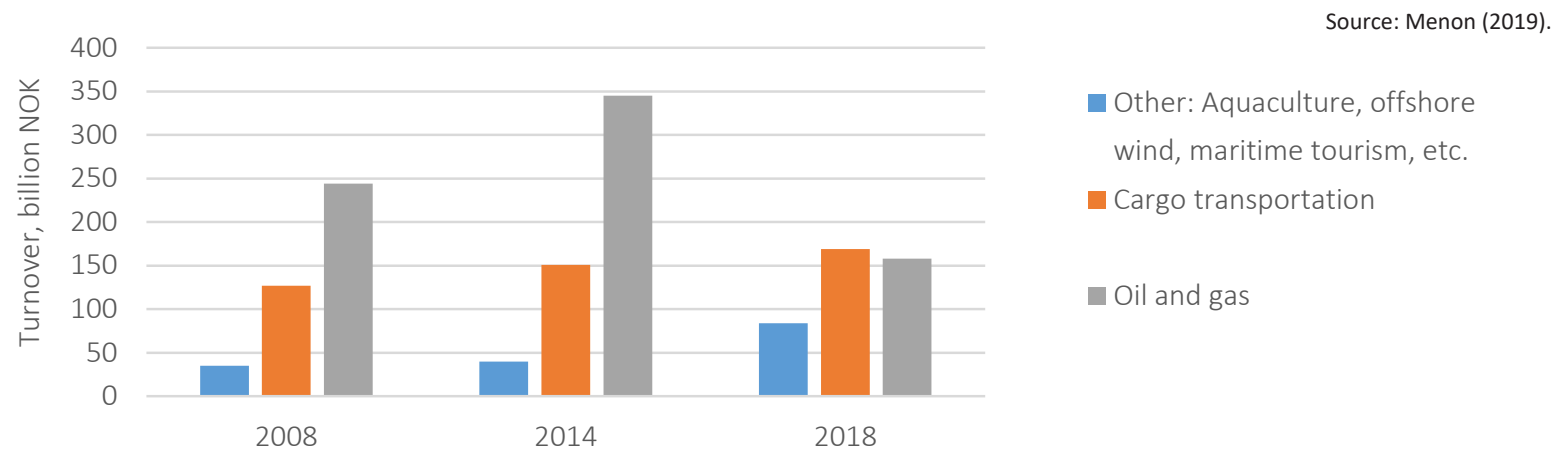

Figure 3. Turnover generated from different market segments (2004-2018)

more traditional shipping (goods transport) slightly contracted. Sustained excess supply in several large markets helped to keep rates and sales down during the same period when the oil and gas market grew strongly. Since the oil crisis from the second half of 2014, turnover in the offshore fleet engaged with oil and gas more than halved. Goods transport remained fairly stable over the same period when other markets are growing significantly. Hence, they are contributing to curb the fall for the shipping industry as a whole. Growth in this part of the industry is driven by growth in new markets such as aquaculture, maritime tourism, offshore wind and other niche markets (Figure 3). Sales in these segments have more than doubled since 2014.

It should be mentioned that the maritime industry in Norway has an international orientation and it is the second-largest contributor to Norwegian export revenues. Exports' share has remained stable at around 50 percent throughout the period between 2010 and 2018.

This description can help to illustrate the challenges facing the industry. Given the international nature of the industry, virtually all customers within a segment are affected equally, regardless of where in the world they are located. The domestic market is closely integrated with the global market.

\section{MARITIME MAIN GROUPS AND SUBGROUPS ANALYSIS}

To answer the research questions (to check the position of the Norwegian maritime industry and to conduct a detailed structural analysis of the key financial indicators of the companies within the cluster), it is necessary to conduct the analysis of the Norwegian maritime cluster through its main groups and subgroups. It should be mentioned that the maritime industry consists of a large number of business types and it is divided into four main segments and ten sub-segments. These are:

- $\quad$ shipping companies: deep-sea shipping companies, offshore shipping companies, short sea shipping, and rig companies;

- design and service providers: financial and legal, port and logistics, technological services and trade;

- equipment manufacturers;

- shipyards.

The value creation in the various groups is illustrated in Figure 4.

Thus, one can see that the shipping companies are responsible for almost $60 \%$ of value creation in the industry, with total value creation of 84 billion NOK in 2018. The various service providers collectively contribute just under $25 \%$ of the value creation in the maritime industry, while the equipment suppliers and shipyards are behind $13 \%$ and $5 \%$, respectively.

Also, the presented analysis reveals that employment is distributed the following way: in 2018, there were about 85,000 employed in the maritime industry in Norway, around 40 percent of the employees in the industry work within the main shipping line, almost 30 percent in services, 20 percent in equipment and the rest in the shipbuilding industry (Figure 5). 


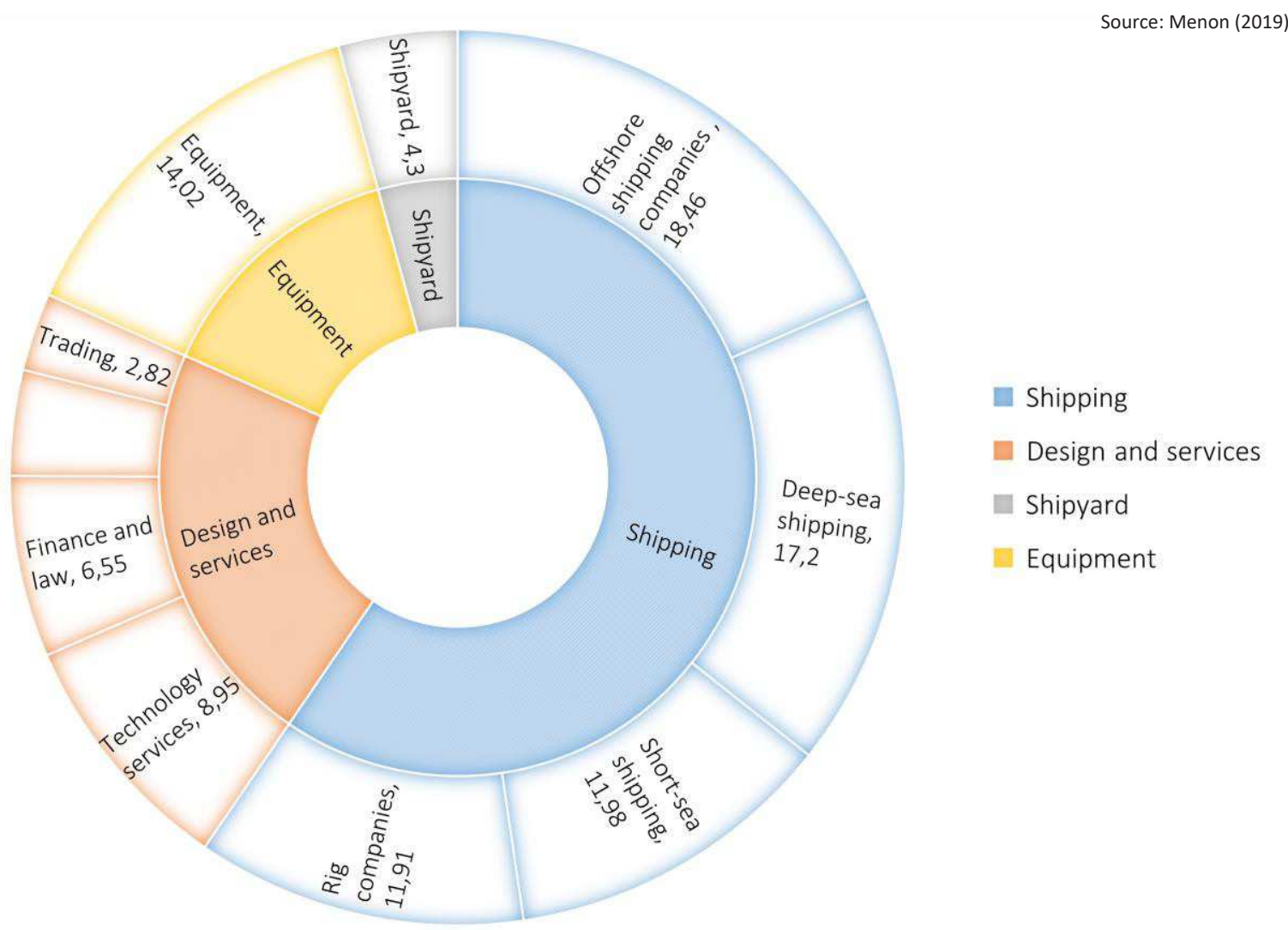

Figure 4. Value creation in main groups and subgroups in 2016 (numbers in billion NOK)

Almost 25,000 employees have left the industry since 2014. If this trend continues, the industry is in danger of losing important skills within the cluster.

A new survey from Statistics Norway shows that there were 21,970 Norwegian seafarers in 2017, down $11 \%$ since 2015 . Around $70 \%$ of the seafarers in 2017 worked on ships registered in NOR. The remaining worked on ships registered in NIS and on other Norwegian ships registered abroad.

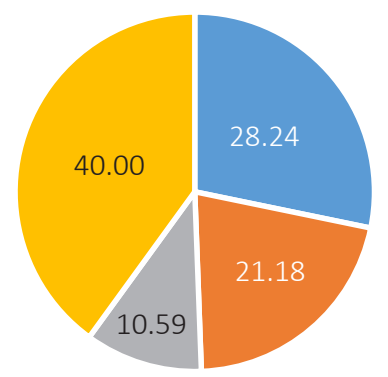

$$
\begin{aligned}
& \text { - Design and services }=\text { Equipment } \\
& \text { - Yards }=\text { Shipping }
\end{aligned}
$$

Talking about the maritime industry globally, it is obvious to believe that the number of Norwegian seafarers will decline, both due to increased use of skilled foreign labor and automatization, especially for subordinate positions. On the other hand, it is stated that the government has initiated an active policy to make shipping companies flag their vessels back to Norway and that the net wage scheme has been important in maintaining the number of domestic seafarers. Vessels sailing under NOR are required to com-
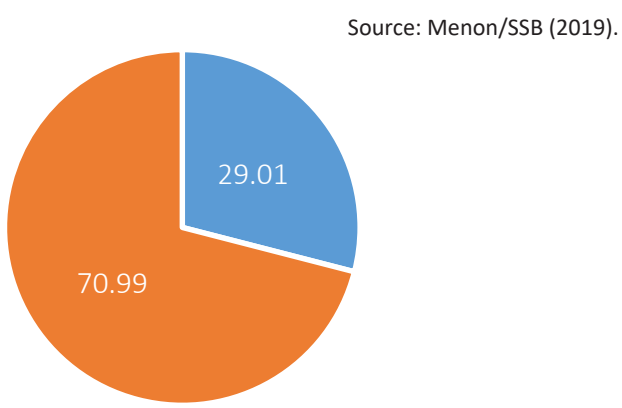

- Number of Norwegian seafarers

- Number of foreign seafarers

Figure 5. Number of persons employed in the maritime industry in 2018 by main groups, $\%$ 
ply with Norwegian payment and working conditions. Consequently, the pressure to hire foreign crew is less for this part of the fleet. Ships registered in the NIS, operated by Norway by Norwegian shipping companies, can hire foreign crews who are paid on their home country's payment terms. As a result, several of the subordinate positions are employees of non-Norwegian citizenship. For ships registered in the NIS, there are some area restrictions to prevent the competition of ships sailing under NOR.

It should be mentioned that in 2016, some changes were introduced for NIS vessels, including a strengthening of the subsidy scheme so that the shipping companies can employ more Norwegian seafarers on NIS-registered vessels. Competitive net pay schemes are crucial in contributing to the recruitment of Norwegian seafarers on Norwegian registered vessels and, thus, ensuring Norwegian operational maritime competence. If Norway is to continue to be a world leader within maritime industries, it is essential to have a competitive maritime policy.

\subsection{Shipping companies}

The Norwegian maritime fleet can be classified as follows: 1) ships registered in the Norwegian Ordinary Ship Register (NOR) or in the Norwegian International Ship Register (NIS) (sailing under the Norwegian flag) and ships flying under a foreign flag (Norwegian-controlled ships); 2) merchant ships, pleasure craft vessels, and naval ships; 3) cargo vessels and non-cargo vessels.
Besides, the Norwegian fleet is divided into three other categories: a) the maritime offshore fleet; b) the short-sea fleet; c) the deep-sea fleet (Koilo, 2019).

The shipping companies are responsible for almost 60 percent of the value creation in the industry. Shipping is a very cyclical industry, and the various subgroups are affected by the demand for their services from different markets. The offshore shipping companies and the rig companies are, of course, strongly influenced by the demand for their services among the oil operators. Turnover among the oil and gas-oriented shipping companies grew sharply during the ten-year period from 2004 to 2014, exemplified by a five-fold increase in turnover among offshore shipping companies. Following the fall in oil prices in 2014, demand for their services fell sharply. Combined with a sustained overtime offer, this has led to both reduced activity and reduced prices in the market.

Since the peak in 2014, turnover has almost halved among the Norwegian offshore shipping companies and rig companies. Deep-sea shipping companies are strongly influenced by world trade and the supply situation for ships worldwide. Despite a strong increase in world trade, deep-sea shipping companies have increased their sales marginally since 2004. The shipping companies have had a steady rise in turnover for a long time, with more than double the turnover from 2004 to 2018. In recent years, strong growth in the short sea shipping industry aimed at the aquaculture industry has helped to keep up growth (Figure 6).

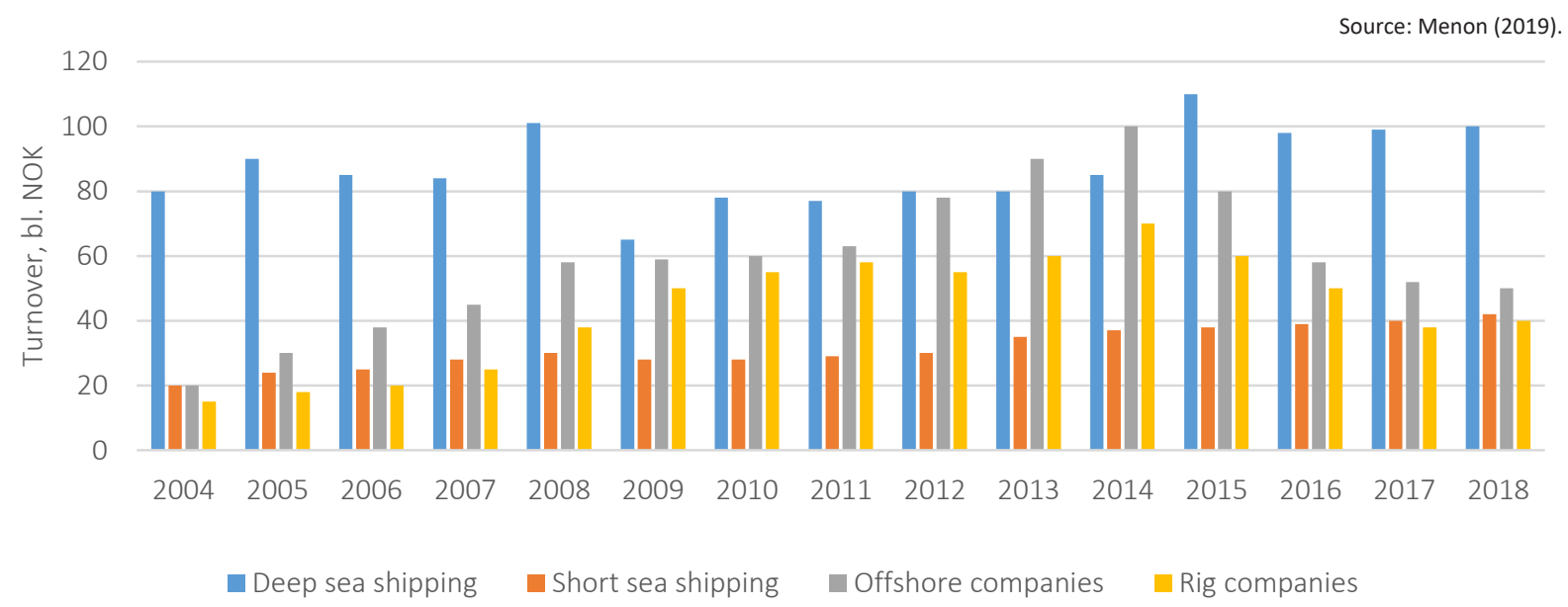

Figure 6. Development of turnover among the various shipping types (2004-2018) 
At the end of 2018, the Norwegian-controlled foreign fleet consisted of 1,800 vessels. The number of ships has been relatively stable over a long period. Of 1,800 vessels, just over 600 are offshore vessels. There is a positive development in NIS register that is still experiencing growth. The NIS fleet has increased by eight percent in number and ten percent in tonnage between 2014 and 2017.

Whilst, the investigation shows that some of the new vessels in NIS have been flagged down from NOR, but overall growth is positive. A large Norwegian fleet is important, among other things, because it has significance for Norway's position in the International Maritime Organization (IMO). Norwegian ship-owners control the world's seventh-largest fleet measured in deadweight tones. Deadweight tons say a lot about the physical size of a country's fleet but in many cases, little about the earning potential. More advanced vessels with relatively high revenue potential concerning deadweight tonnage are not captured by measuring the physical size of the fleets. An alternative measure for assessing a fleet's earning potential is, therefore, the total value of the fleet. The Norwegian share of the world fleet measured in value for different segments in 2018 shows how Norwegian shipping companies have large market shares within selected segments. Especially in offshore and car freight (Ro-Ro), Norwegian shipping companies are very strong, but also in the shipping of gas and chemicals, Norwegian players have large market shares.

Deep-sea segment. Ninety percent of international trade is transported by ships. The world economy, thus, depends on the efforts of deep-sea shipping companies. Norwegian shipping companies have large market shares in several niches such as Ro-Ro, chemicals, and gas. In recent decades, there has hardly been any growth in the overall activity of Norwegian deep-sea shipping companies. This is partly because Norwegian shipping companies rather have focused on activities related to petroleum activities. Historically, of course, there is a strong correlation between freight rates and deepsea shipping's financial performance (Grytten \& Koilo, 2019). The Clark Sea Index measures average freight rates for the world's merchant fleet. In the years from 2006 to 2008, the Clark Sea Index was around $\$ 30,000$ per day. The financial crisis, together with record-high newbuilding activity, led to a fall in both demand and supply of ships. The world economy has gradually recovered, but the supply of ships in the market has been stable. Despite sustained low freight rates, Norwegian deep-sea shipping companies have adapted to the new situation and have delivered good results since 2013.

Short sea segment. The shipping companies are an important part of the Norwegian maritime industry, with almost 20 billion NOK in value creation and 14,000 employees in 2018. Every day, more than 100 Norwegian-controlled ships call European ports. The largest players carrying passengers are Color Line, Torghatten, Fjord1, and Hurtigruten. In the field of freight transport, Wilson and Sea-Cargo are the two largest players in Norway.

Offshore shipping companies. After many years of strong growth, activity levels and profitability have fallen significantly for offshore shipping companies since the fall in oil prices. From the peak year in 2014, turnover was almost down to a half in 2018, and operating margins have been negative in all years since 2014. Today's market situation has arisen as a consequence of reduced demand for offshore shipping companies' services, combined with very high newbuilding activity in the period before the fall in oil prices. Offshore shipping companies took large loans for the construction of new ships during the upturn and built up high debt. In the period of high activity and high rates, this was not a problem as the income was far higher than operating and financial costs. However, with significantly lower revenues since 2015 , several of the offshore shipping companies have experienced significant liquidity challenges. From 2015 to 2017, one saw negative operating margins of below $30 \%$.

Rig companies. The oil and gas companies have largely contracted out ownership and operation of drilling rigs and production units to rig companies. Norway sits on a long-held leading position in this field. From 2007 to 2014, there were about 60 Norwegian-controlled rigs in the fleet. As a result of a sharp fall in oil prices and increased cost focus on the oil operators, the number of Norwegian rigs is declining and several of them are not active. The activity among the rig companies increased 
somewhat in 2018 , but there are still too many rigs. The market for drilling and production services has traditionally been regional. However, it has gradually become more global with companies such as Seadrill and American Transocean (both with Norwegian background) as the world's two leading players. In 2012, Seadrill relocated its head office from Stavanger to London. In 2011, North Atlantic Drilling was excreted as a subsidiary of Seadrill, with a focus on weather operations in deep water.

\subsection{Maritime service and design}

The current analysis shows that maritime service providers employ 25,000 people in Norway, turnover in 2016 amounted to 82 billion NOK, almost 22 percent of the value creation in the industry. During the last three years (2016-2018), value creation growth was minus $12 \%$, somewhat better than the industry as a whole. Shipping companies depend on deliveries from a wide range of maritime service providers, the most important of which are ship financing, insurance, brokerage, maritime law, ship design, classification and port services. The main group consists of four subgroups of companies consisting of:

- financial and legal services;

- port and logistics services;

- technological services;

- trading;

- design.

Norway has one of the world's most comprehensive maritime service environments, and Norwegian companies are among the largest and most significant in the world in several areas, e.g., DNB and Nordea (with their shipping headquarters in Norway). They are the world's two largest ship financing facilitators. Gard and Skuld are among the leading suppliers of maritime insurance, and Fearnley and Clarkson Platou are similar in ship brokering. Also, in the field of research, Norwegian actors are internationally prominent, such as the Nordic Institute of Maritime Law at the University of Oslo, the Marine Institute of Technology at NTNU, SINTEF Ocean and several regional colleges.

Technological services. Norway has been a technological leader in the maritime industry for decades, with significant contributions from players in technological services. Technological services consist of a wide range of business types, such as classification, engineering services, technological $\mathrm{R} \& \mathrm{D}$, ship design and installation work. In total, this group had sales of 31 billion NOK in 2018, an increase of 5 percent from the previous year. Profitability is still low, with an overall operating margin just above 0 (Figure 7).

To conclude, the value of the companies is created to a greater extent by the employees of the companies than in more capital-intensive segments of the maritime industry.

Financial and legal services. The maritime financial and legal services have a total turnover of about 14 billion NOK, distributed around 2,300 employees. Financial and legal services generally have high margins and high-value creation per employee. Shipping operations are very capital intensive, which means that lenders and financial

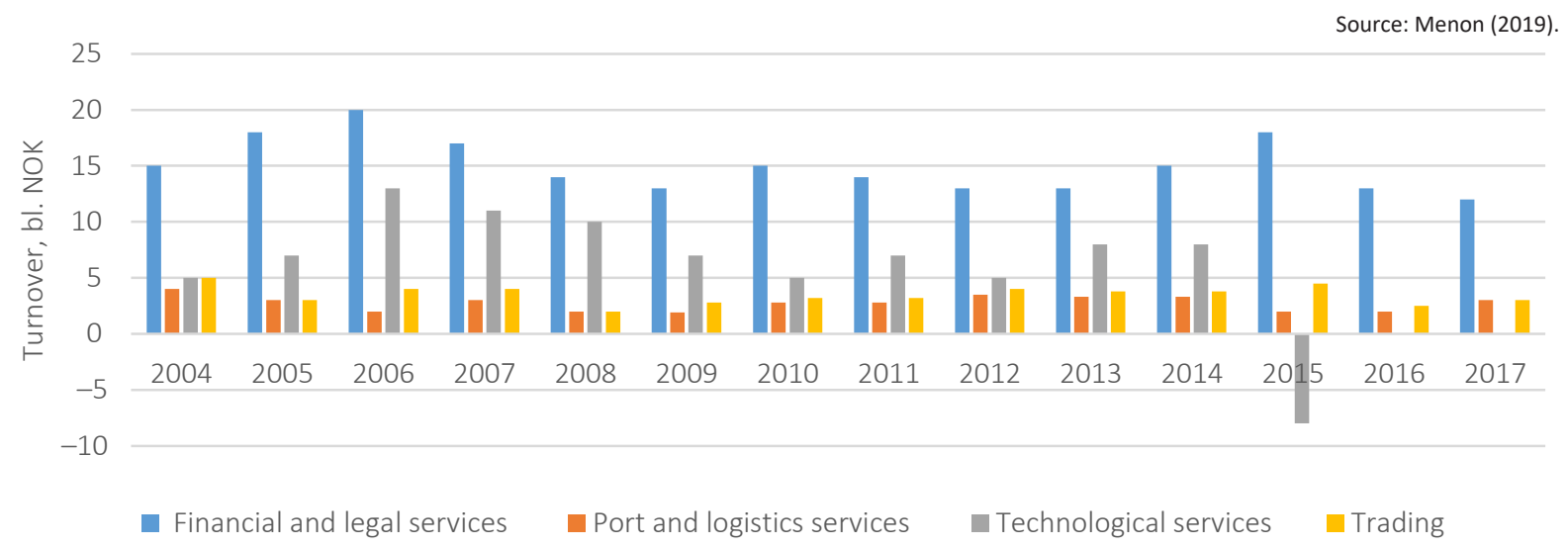

Figure 7. Development in operating margin among service providers (2004-2018) 
facilitators are of central importance. Besides, the shipping markets are very volatile.

Port and logistics services. The providers of logistics services operate in international markets, while port operations and supply bases are typical local services. In total, they had around 350 suppliers of port and logistics services with a total turnover of 13 billion NOK in 2018. Regionally, Stavanger, Bergen, Mid-Norway, and ports in Northern Norway are the most important areas. Large parts of the business are linked to oil and gas activities.

\subsection{Shipyards}

The shipbuilding industry is still important for Norway. Only a few countries in Europe still have an active shipbuilding industry. The reason why the Norwegian shipbuilding industry has survived is multi casual, and the high level of innovation and adaptability is central. In recent years, the industry has again been tested for its adaptability. For a long time, the construction of offshore vessels has driven around 80-90 percent of the activity at Norwegian shipyards, but in the last three years, this market has completely dried up (Figure 8). Restructuring, new innovative solutions and new growth opportunities in the ocean space will be central to the industry's further development.

It is worth mentioning that in the last two years, order books have grown strongly in Norwegian shipyards and at the beginning of 2019, total almost 50 billion NOK. Cruise ships, ferries, well boats, and fishing vessels now dominate the order books.
There are small and medium-sized yards along the Norwegian coast. These focus on the construction of smaller ships or special market niches. Besides, repair and maintenance are often important activity drivers. An example is Fjellstrand, which built Norway's first battery ferry. The brothers Aa in Sogn and Fjordane produce fast boats in carbon fiber composite materials. Besides, several smaller yards produce recreational boats. Viknes, Windy, Goldfish, Saga, Ibiza, and Skibsplast are examples of Norwegian players in this group. Several smaller shipyards have delivered relatively good results in recent years as a result of deliveries to the aquaculture industry. Kleven, Vard, Havyard, and Ulstein are the four largest shipyard groups in Norway and all have their headquarters in Møre og Romsdal. These yards have been very long aimed at the lucrative offshore market, which in turn has led to major losses in recent years. However, shipyards have partially succeeded in maintaining the activity through deliveries to new market segments such as fishing and expedition cruises. However, the profitability of these projects has not been close to the levels from the offshore boom.

\subsection{Equipment manufacturers}

On a Norwegian built ship, there will typically be dozens of Norwegian equipment suppliers involved. Until 2014, turnover among equipment suppliers grew sharply. This is partly due to increased demand for Norwegian shipyards and among Norwegian shipping companies, but mainly because growth has been strong within the offshore segment, where Norwegian players have succeeded internationally. The equipment manu-

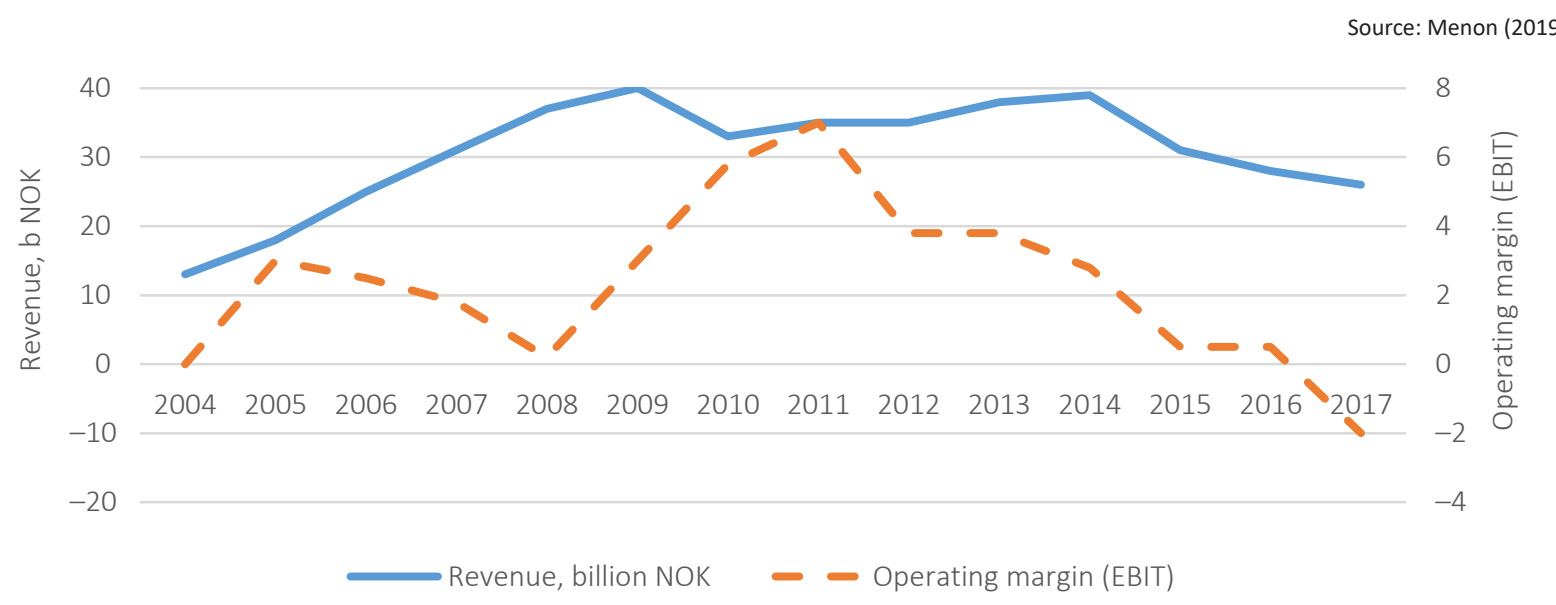

Figure 8. Turnover and operating margin among the shipyards (2014-2017) 


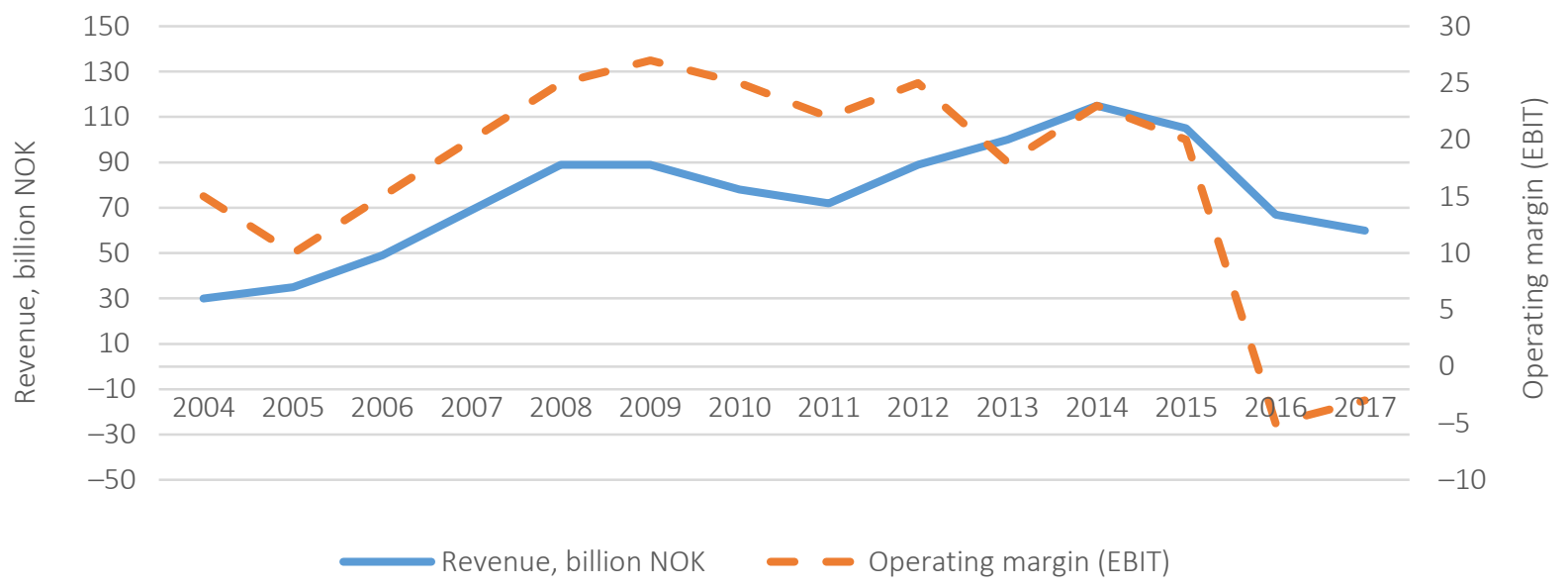

Figure 9. Turnover and operating margin among equipment suppliers (2004-2017)

facturers, like many others, have been hit hard by the downturn in offshore 2014-2017. Turnover has almost halved since 2014 overall, but the situation is not as bleak for most players (Figure 9).

Overall, a large proportion of the fall in equipment suppliers is due to a drastic decline in drilling equipment orders worldwide. Among companies that do not supply drilling equipment, the fall in the same period is limited to around 25 percent.

Norwegian equipment manufacturers are spread across a wide range of product groups, more or less specialized towards ship segments and other floating facilities. Kongsberg Maritime is the world's leading supplier of dynamic positioning (DP) and also holds international positions in control and surveillance systems. The Kristiansand based companies NOV (National Oilwell Varco) and MHWirth dominate the world market for drilling equipment. With 20 percent global market share, Jotun is a world-leading manufacturer of the ship and offshore paint. Rolls-Royce Marine and Siemens in Norway are among the world's leading engine and propulsion system manufacturers. IP Houses, Macgregor, TTS, and Brunvoll are all equipment manufacturers in Norway with a strong international position in their markets.

The abovementioned analysis proves that the financial performance of the companies, which belong to the maritime cluster, is deeply connected with the productivity and performance of the oil and gas industry. Nevertheless, companies with a more diversified portfolio were able to meet the hard years better than others. Thus, it's important to check this assumption and to proceed with the analysis of the companies' financial state.

\section{METHODOLOGY}

To carry out this study, one needs to gather key indicators of the financial activity of the companies. It was natural to conduct the analysis on one of the complete maritime clusters, located at Møre og Romsdal, usually called the Blue Maritime Cluster (BMC).

The data were collected from the reports made by Menon and the Norwegian central company register at Brønnøysundregistrene, the current study employs annual time series from 2001 to 2018.

The analysis sheds light on the financial state of companies that belong to different branches of the maritime industry (shipyards and shipping companies), thus, we can study the chain reaction in the maritime supply chain.

The proposed analysis includes the following steps.

First step. Formation of the system of indicators, which reflects the financial state of the companies and design of the information database. The model is based on six indicators, which characterize the financial state of eight different companies of the BMC: 
- $\quad$ total rentability (TOT_REN);

- operational returns (OP_RET);

- equity rentability (EQ_REN);

- liquidity ratio (LIQ_RAT);

- equity ratio (EQ_RAT);

- debt ratio (DEB_RAT).

Second step. Normalization of the input data. Since different indicators have different measurement scales, it is necessary to carry out standardization in order to make the data comparable. It should be noted that indicators could have a different effect on the result parameter, thus, we apply the following method of normalization of indicators used in mathematical statistics:

- for stimulating indicators - natural normalization:

$$
x_{i j}(s t)=\frac{\max \left(y_{i j}\right)-y_{i j}}{\max \left(y_{i j}\right)-\min \left(y_{i j}\right)} ;
$$

for destimulating indicators - savage normalization:

$$
x_{i j}(d e s)=\frac{y_{i j}-\min \left(y_{i j}\right)}{\max \left(y_{i j}\right)-\min \left(y_{i j}\right)} ;
$$

where $x_{i j}(s t)$ - a normalized value of the stimulating indicator, $x_{i j}($ des $)$ - a normalized value of the destimulating indicator, $\min \left(y_{i j}\right)-$ minimum value of the relevant indicator during the $t$ year period and $\max \left(y_{i j}\right)$ - maximum value of the relevant indicator during the $t$-year period.
Third stage. The optimization process of the input data is based on Harrington's desirability function. Harrington's overall function or desirability function can be a quantitative and universal measurement tool that provides an assessment of the quality of an object under study and can be used as an optimization criterion. In order to use the Harrington's function, all indices must be dimensionless (normalized) and the partial functions of Harrington (equations 3 and 4) should be determined:

$$
\begin{aligned}
& h_{k}=\exp \left(-\exp \left(-x_{k}\right)\right), \\
& H_{i}=\sqrt[n]{\prod_{k=1}^{n} h_{k}},
\end{aligned}
$$

where $k$ is the number of indicators used to assess the level of desirability, $h_{k}$ - partial functions determined according to the Harrington's scale, $x_{k}$ - dimensionless index, $n$ - the number of objects being investigated.

Graphically, the function can be presented as follows (Figure 10).

It should be noted that calculated partial coefficients will allow us to estimate, with mathematical accuracy, the advantages and disadvantages of the studied objects.

If the desirability factor is in the lower Harrington's area, then, to improve the performance of a particular company, it would be necessary to improve all system parameters to a satisfactory level. If the coefficient of the Harrington's function is located

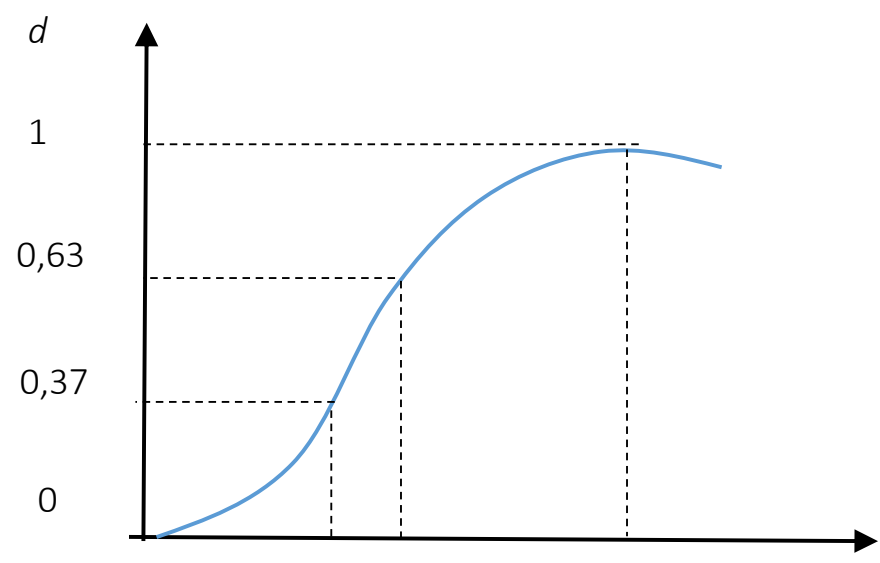

Figure 10. Harrington's desirability function 
in the interval $[0.2 ; 0.8]$, even a small change in the performance of the company can significantly improve the desirability of the function. If the system has an overall coefficient of desirability $[0.8 ; 0.9]$, it can be stated that the enterprise is close to the limit of its own development. Improving its characteristics by increasing its parameter values will require high costs and finding new ways to develop it. To interpret the indicators, Table 3 illustrates an estimation scale of the Harrington's function (Tangparitkul, 2018).

Table 3. Harrington's function rating scale

\begin{tabular}{l|c}
\hline \multicolumn{1}{c|}{ Desirability } & Desirability scale \\
\hline Excellent & {$[0.80-1.00]$} \\
\hline Good & {$[0.63-0.80)$} \\
\hline Satisfied & {$[0.37-0.63)$} \\
\hline Poor & {$[0.20-0.37)$} \\
\hdashline Worst & {$[0.00-0.20)$} \\
\hline
\end{tabular}

Hence, the process of analyzing the partial coefficients of the desirability function allows evaluating the financial state of a company, on the one hand, and to find out the directions of further development of a particular entity of the business, on the other hand.

Fourth step. Clustering analysis and dendrogram construction.

Clustering analysis aims to organize the investigated objects into meaningful structures to gain further insight from them. In our analysis, it will allow us to determine the hierarchical relationship between the companies within the cluster and check the Norwegian maritime industries strategic strength in light of future challenges and the green shift.

In clustering analysis observations and variables can be clustered using various distance measures (Euclidean distance, Euclidean square, Manhattan, Chebyshev, etc.) In this analysis, we will use Euclidean distance; it can be determined using the following equation:

$$
p_{E}\left(x_{i}, x_{j}\right)=\sqrt{\left(x_{i}^{1,2, k}-x_{j}^{1,2, k}\right)^{2}} .
$$

The Euclidean distance matrix displays the similarities and differences in the financial performance of different companies. The smaller the value, the higher the degree of similarity between the two companies and combinations in the cluster. Conversely, the greater the corresponding value, the greater the difference between companies.

\section{RESULTS}

In the process of determining the financial state of the companies, which belong to the maritime cluster, we use the data of four shipping companies and four shipyards in the period 2001-2018. Thus, using equations (1-3), the partial functions, determined according to the Harrington's scale, have the following form (Table 4).

Table 4. Partial functions determined according to the Harrington's scale

Source: Author's calculations.

\begin{tabular}{|c|c|c|c|c|}
\hline \multirow{2}{*}{ Indicator } & \multicolumn{4}{|c|}{ Shipping company } \\
\hline & Company 1 & Company 2 & Company 3 & Company 4 \\
\hline TOT_REN & 0.14 & 0.25 & 0.28 & 0.17 \\
\hline OP_RET & 0.14 & 0.27 & 0.30 & 0.17 \\
\hline EQ_REN & 0.29 & 0.16 & 0.14 & 0.16 \\
\hline LIQ_RAT & 0.15 & 0.19 & 0.11 & 0.16 \\
\hline EQ_RAT & 0.23 & 0.25 & 0.22 & 0.14 \\
\hline DEB_RAT & 0.22 & 0.25 & 0.22 & 0.14 \\
\hline \multirow{2}{*}{ Indicator } & \multicolumn{4}{|c|}{ Shipyards } \\
\hline & Company 5 & Company 6 & Company 7 & Company 8 \\
\hline TOT_REN & 0.17 & 0.18 & 0.18 & 0.20 \\
\hline OP_RET & 0.19 & 0.21 & 0.28 & 0.22 \\
\hline EQ_REN & 0.21 & 0.09 & 0.22 & 0.23 \\
\hline LIQ_RAT & 0.18 & 0.16 & 0.25 & 0.20 \\
\hline EQ_RAT & 0.22 & 0.22 & 0.20 & 0.17 \\
\hline DEB_RAT & 0.22 & 0.24 & 0.20 & 0.17 \\
\hline
\end{tabular}




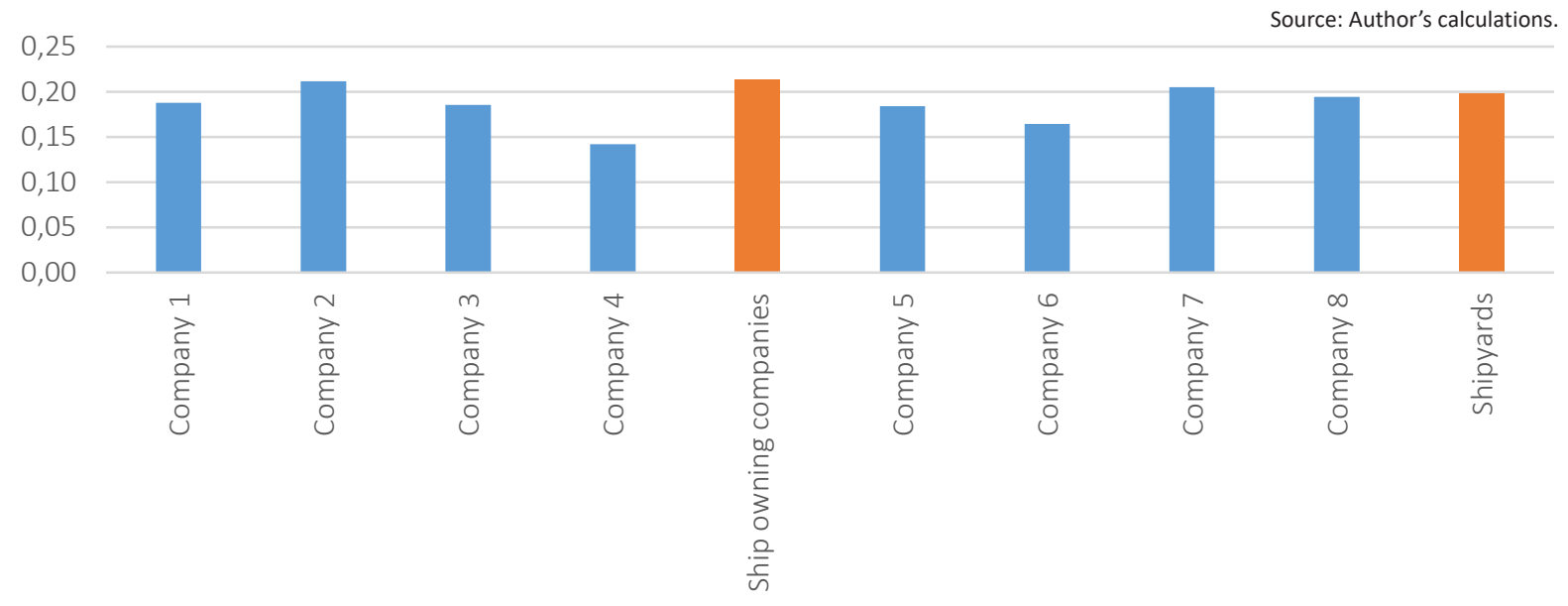

Figure 11. The value of the integral index of the financial state of the shipping companies and shipyards

The results, depicted in Table 4, reveal that all partial functions (coefficients) for all eight companies are in the lower Harrington's area. Hence, to improve the financial state, it is necessary to improve all system parameters to a satisfactory level.

Generally, the results of calculations of the integral indicator of financial stability for the sampling groups of companies, according to equation (4), presented in Figure 11.

The results of the assessment presented in Figure 11 primarily indicate the problems of functioning of companies, which belong to $\mathrm{BMC}$, in the period 2001-2018.

It is imperative to pay attention that the value of the integral index of the financial state of the shipping companies and shipyards do not exceed the limit of 0.21 , hence, companies are experiencing poor financial performance, especially in the last five years (Figure 12), which corresponds to the deepening of crisis phenomena in the maritime sector due to the crisis in oil and gas industry in 2014.

So, we can see that during the analyzed period, companies had a satisfactory level of a financial state (with a peak of 0,35 for shipping companies in 2002 and 0,32 for the shipyards in 2011). Nevertheless, there were several fluctuations and the most significant troughs happened after 2014 until 2018.

Generally speaking, the overall trend of the financial state of the companies that belong to BMC

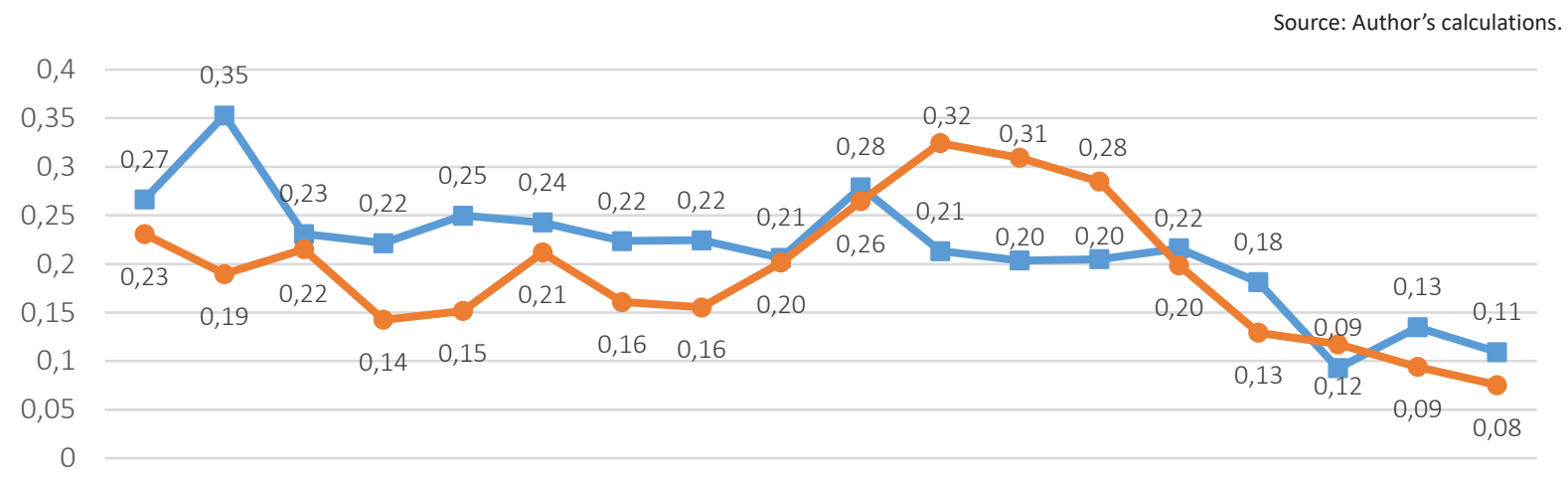

200120022003200420052006200720082009201020112012201320142015201620172018

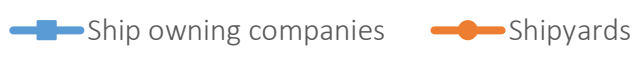

Figure 12. The dynamics of the integral index of the financial state of the shipping companies and shipyards in a period 2001-2018 


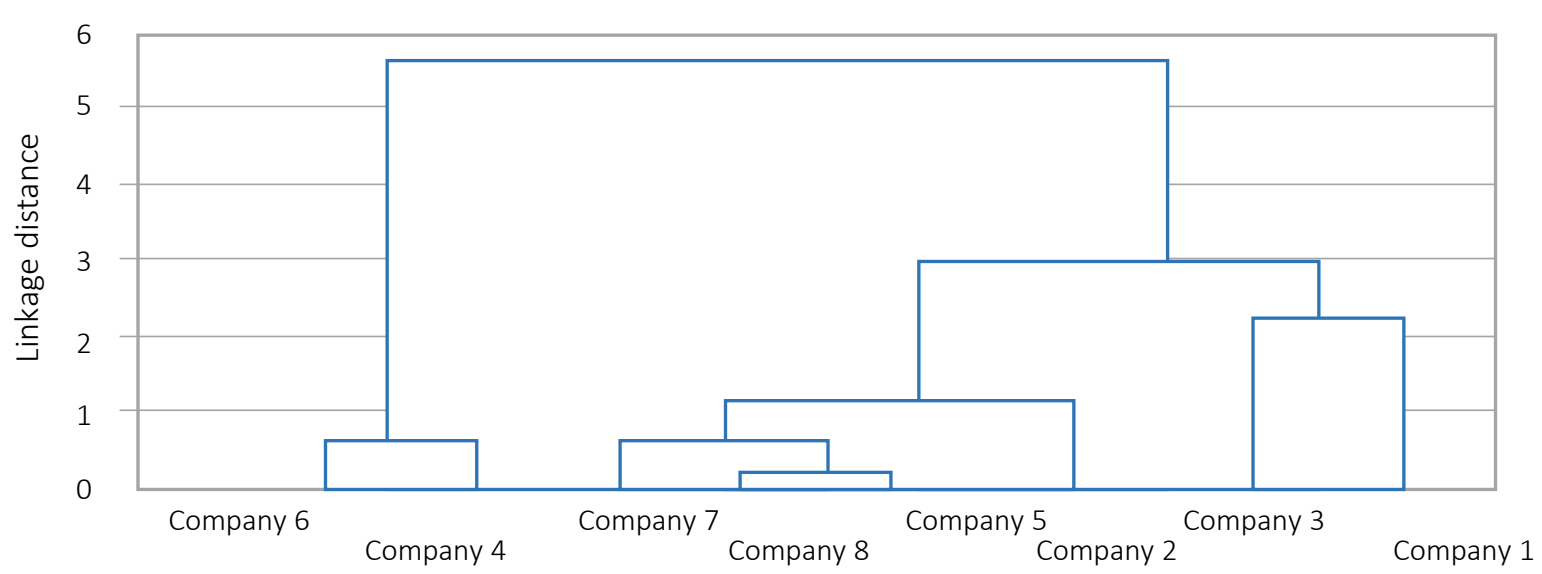

Figure 13. Hierarchical classification of shipping companies and shipyards

can be characterized as negative. That proves the statement about negative shifts in the companies' activity.

The last step of the analysis is to determine the hierarchical relationship between the companies. The distance between the objects is taken usually using Euclidean distance.

The result of this stage is the construction of a dendrogram diagram using STATISTICA 10, which gives the first idea of the number of possible clusters (Figure 13).

As a result of the construction of the dendrogram, it is possible to form a hypothesis about the presence of at least three clusters. They can be defined as follows: the first cluster includes two companies with lower level of the financial performance, and, at the same time, according to our assessment of the integral index, they have unsatisfactory level of financial state (Company 4 and Company 6); the third cluster is presented by Company 1 and Company 3 with medium level of financial performance; and the second one includes four companies, which are experiencing better financial state (shipyards - Companies 5,7 and 8, and shippingCompany 2).

The obtained results reveal that shipyards have a more homogeneous relationship between each other, hence, the financial state does not differ a lot, while shipping companies show different performances during the period and, in addition, heterogeneity within the group.

\section{DISCUSSION}

The Norwegian maritime industry has been technologically leading for decades. New Norwegian solutions have, thus, affected maritime industries globally. Many of the innovative solutions are characterized by environmentally friendly technologies. Thus, the Norwegian maritime industry contributes to creating a greener footprint on the world seas.

In addition, players in the Norwegian industry are pushing for a number of environmentally-friendly innovative solutions in fields such as (Menon, 2019):

- hole fouling (hull fouling) - purification technologies to prevent biological growth on various parts of the hull and to prevent marine pollution;

- scrubbers - the marine industry is now in the initial phase of the development of maritime scrubbers, i.e., installations that "wash" gas and catch drops. In this way, $\mathrm{CO} 2$ emissions are reduced, while sulfur emissions are almost eliminated;

- $\quad$ ship design optimization - significant energy savings can be found using ship-efficient energy design solutions for shape and ship painting;

handling ballast water, gray water, and black water - work is underway to develop systems for wastewater treatment of ships. 
In light of the present analysis, maritime companies are faced with many important tasks, and especially two: to improve their financial state and to understand their impact or dependence on ocean sustainability. Both should be incorporated into their sustainability policies, taking a full value-chain perspective.

To stay at the forefront of the maritime industry, Norwegian companies need better economic incentives, which help them to keep their leading position in the technological aspect and ensure value creation within the industry.

In 2015, a maritime strategy called "Maritime Opportunities - Blue Growth for a Green Future" was presented, which was launched by the Norwegian government (Norwegian Ministry of Trade, Industry, and Fisheries, 2015). This program presents a set of actions, which aim to stimulate greener ship construction, to strengthen the general support of comprehensive research, development, and innovation in the maritime industry and also aims at harmonizing global regulatory frameworks. Besides, there are several cluster programs, which support R\&D and training activities. Nowadays, there are three maritime clusters, which are supported by Innovation Norway: Arena, Norwegian Centers of Expertise (NCE), and Global Centers of Expertise (GCE) (OECD, 2017).

Hence, the green growth for the Norwegian maritime industry is significantly stimulated by the Norwegian government. Nevertheless, maritime companies still need various public support measures that can affect industrial capacity, e.g., the government can propose different financial instruments and solutions that can help to reduce or manage the financial risks of firms. The authorities should strengthen the attractiveness of the Norwegian flag, strengthen the tax refund and net wage schemes for Norwegian seafarers on Norwegian registered ships and maintain a competitive Norwegian tonnage tax scheme.

\section{CONCLUSION AND FURTHER STUDIES}

The present study analyzes the performance of the Norwegian maritime industry in terms of its economic activity during the period 2001-2018 and to determine the effect of 2015-2017 offshore crisis on the Norwegian maritime cluster activity and in particular some main actors of the industry.

The results of this investigation show that the financial performance of firms, which belong to the maritime cluster, is deeply connected with the productivity of the oil and gas industry. Nevertheless, companies with a more diversified portfolio were able to meet the hard years better than others.

This present paper uses a Harrington's desirability function to measure the firms' financial state of two main segments (shipping companies and shipyards), that belong to the Blue Maritime Cluster of Møre and Romsdal county. The obtained results reveal that during the analyzed period (2001-2018), companies had a satisfactory level of financial stability until 2014, with a peak in 2002 for shipping firms and in 2011 for the shipyards, nevertheless, there were several fluctuations and the most significant troughs came after 2014. The purpose of the study was also to determine the hierarchical relationship between the companies. Thus, when conducting cluster analysis, the current paper reveals that shipyards have a more inter-homogeneous relationship. Hence, the financial state of these companies does not differ a lot, while shipping companies show another tendency - different performance during the period and heterogeneity within this sub-group.

The results of the study also highlight the significance of government support and incentives in the maritime industry, and contribution of the state to a more environmentally friendly shipping fleet.

It should be noted that every study has limitations. In this paper, it has not been possible to investigate the level of contribution of the businesses in striving to achieve SDGs further, because the sample size 
was too small (there is a need to extend a set of variables, e.g., social and environmental indicators). Therefore, future researchers can conduct surveys on how exactly companies comply with sustainability criteria. Also, further data collection is required to determine more precisely how SDGs affects the financial state of the companies - can they be controversial for different business entities within the same sector or not?

\section{REFERENCES}

1. Asheim, B., Grillitsch, M., \& Trippl, M. (2016). Smart Specialization as an innovation-driven strategy for economic diversification: Examples from Scandinavian regions (Paper in Innovation Studies 2016/23). Lund University CIRCLE - Center for Innovation, Research and Competences in the Learning Economy. Retrieved from https://ideas.repec.org/p/ hhs/lucirc/2016_023.html

2. Cluster Maritimo Espanol. (2006). Quantification and Economic Impact of the Maritime Sector.

3. Doloreux, D., \& Shearmur, R. (2009). Maritime clusters in diverse regional contexts: The case of Canada. Marine Policy, 33(3), 520-527. https://doi.org/10.1016/j. marpol.2008.12.001

4. European Commission. Maritime affairs (2008). The role of Maritime Clusters to enhance the strength and development of maritime sectors. Retrieved from https:// ec.europa.eu/maritimeaffairs/documentation/studies/clusters_en

5. Grytten, O. H., \& Koilo, V. (2019). Norske maritime noeringer i endring: krise og utfordring. https://doi.org/10.13140/ RG.2.2.12143.59047

6. Hansen, J. F., \& Clasen, J. K. (2010). The Economics Significance of Maritime Clusters. Retrieved from https://pdfs.semanticscholar. org/05b7/502de9eca30aca4004852 d77ce0f2ecb3bcf.pdf

7. Koilo, V., \& Grytten, O. H. (2019). The Blue Maritime Cluster Crisis Financial Instability and Supply Chain Management Effects (Discusssion Paper SAM15). Department of Economics. NHH. Retrieved from https://ideas.repec. org/p/hhs/nhheco/2019_015.html
8. Koilo, V. (2019b). Sustainability issues in maritime transport and main challenges of the shipping industry. Environmental Economics, 10(1), 48-65. http://dx.doi. org/10.21511/ee.10(1).2019.04

9. Langlois, R., \& Robertson, P. (1996). Stop Crying over Spilt Knowledge: A Critical Look at the Theory of Spillovers and Technical Change (University of Connecticut Department of Economics Working Paper Series. Connecticut). Retrieved from http://digitalcommons.uconn.edu/cgi/viewcontent. cgi? article $=1340 \&$ context $=$ econ wpapers

10. Maticiuc, M. (2014). Top-down and bottom-up cluster initiatives in Europe. Annals of the University of Petroşani, Economics, 14(1), 205-212. Retrieved from https:// ideas.repec.org/a/pet/annals/ v14y2014i1p205-212.html

11. Meersman, H., \& Voorde, V. E. (1997). Cooperation and strategic alliances in the maritime sector and port industry. Proceedings International NAV \& HSMC Conference.

12. Menon (2018). GCE Blue Maritime 2018 - Global Performance Benchmark. Menon Publication 89/2018. Retrieved from https://www.bluemaritimecluster.no/download?objectPath=/ upload_images/D3591BDCAB4C444AB474CA1F4AD10826.pdf

13. Menon (2019). Maritim verdiskapningsbok 2019. Maritime Forum. Retrieved from https://r. wrepit.net/menon/mv2019/ sec/95\#report-top

14. Mylonas, P., Wallace, M., \& Kollias, S. (2004). Using k-nearest neighbor and feature selection as an improvement to hierarchical clustering (Proceedings of 3rd Hellenic Con- ference on Artificial Intelligence). Samos, Greece. Retrieved from https://link.springer.com/chapte r/10.1007/978-3-540-24674-9_21

15. Norwegian Ministry of Trade, Industry and Fisheries (2015). Maritime Opportunities - Blue Growth for a Green Future. The Government's maritime strategy. Retrieved from https://www. regjeringen.no/en/dokumenter/ maritime-opportunities--bluegrowth-for-a-green-future/ id2413857/

16. OECD (2007). Competitive Regional Clusters: National Policy Approaches. Retrieved from https://www.oecd.org/cfe/regional-policy/competitiveregionalclustersnationalpolicyapproaches.htm

17. OECD (2017). Peer review of Norway's shipbuilding industry. Retrieved from https://www.oecd. org/sti/ind/PeerReviewNorway_ FINAL.pdf

18. Porter, M. (1990). The competitive advantage of nations. Macmillan: London. Retrieved from http:// www.economie.ens.fr/IMG/pdf/ porter_1990_-_the_competitive_ advantage_of_nations.pdf

19. Porter, M. (1998). Systems of innovation: growth, competitiveness, and employment. Harvard Business Press: Boston.

20. Proff (2019). Companies' consolidated financial statements. The Business Finder. Retrieved from https://www.proff.no/

21. Spencer, G. M., Vinodrai, T., Gertler, M. S., \& Wolfe, D. A. (2010). Do Clusters Make a Difference? Defining and Assessing their Economic Performance. Regional Studies, 44(6), 697-715. https://doi. org/10.1080/00343400903107736 
22. Statistics Norway (SBB) (2019). Statistics Norway (dataset). Retrieved from https://www.ssb. no/en/

23. Tangparitkul, S. J. (2018). Evaluation of effecting factors on oil recovery using the desirability function. Journal of Petroleum Exploration and Production Technology, 4(8), 1199-1208. https:// doi.org/10.1007/s13202-0180438-3

24. The European Cluster Memorandum. (n.d.). Promotion European Innovation through Clusters: An Agenda for Policy Action. Retrieved from https://www. clusterportal-bw.de/

25. UNCTAD (2019). The Review of Maritime Transport 2018. United
Nations Report. Retrieved from https://unctad.org/en/PublicationsLibrary/rmt2018_en.pdf

26. Vanaale, E. (2012). Trade and shipping in global scale - impact on the Baltic (Presentation at Baltic Ports Conference, 6.9.2012). Turku, Finland.

27. Vienna Cluster Manifesto (2012). Recommendations issued following the European Cluster Conference 2012 (Ref. Ares (2014)72395 - 15/01/2014). Retrieved from http://ec.europa.eu/DocsRoom/ documents/316/attachments/1/ translations/en/renditions/pdf

28. Voorde, E. E. M. (2005). What future the maritime sector? Some considerations on globalization, co-operation, and market power. Global Competition in Transportation Markets: Analysis and Policy Making. Transportation Economics, 13. https://doi.org/10.1016/S07398859(05)13012-1

29. Wihlborg, M. (2006, August). Employment trends in all sectors related to the sea or using sea resources: Country report - Sweden (European Commission DG Fisheries and Maritime Affairs). ECOTEC Research \& Consulting.

30. Wijnolst, N., Jenssen, J. I., \& Sodal, S. (2008). European maritime clusters. Agder University College, Faculty of Economics and Social Science and DUP Satellite, Delft University Press. 